Socialist Studies: the Journal of the Society for Socialist Studies 6(1) Spring 2010: 1-10

Copyright (C) 2010 The Author(s)

EDITORIAL

\title{
Post-Colonialism, Post Socialism, and Multiple Remembrances
}

CHAD D. THOMPSON

University College of the North. Thompson, Manitoba, Canada.

\author{
Keywords \\ post-socialism • post-colonialism •1989; 1991; Oka; Kanehsatà:ke \\ Mots-clés \\ post-socialisme • post-colonialisme • $1989 \bullet 1991 \bullet$ Oka • Kanehsatà:ke
}

On the morning of 12 July 1990, I flipped on my TV to CNN's Headline News. I received about two hours of English-language television each morning, and had grown dependent on CNN to let me know in the vaguest sense what was going on in the world. I was living in Prague, in what would remain Czechoslovakia for another couple of years, part of the swarm of do-gooders, curiosity-seekers, and carpetbaggers descending on the entire former East Bloc at the end of 1989. By the time I left Prague, it was clear to anyone who looked carefully that the new regime's willingness to suspend visa and currency regulations made 'English teacher' a surprisingly lucrative moniker for anyone looking to cash in quickly before the heavyweights took over, and in the process thoroughly elided any boundary between do-gooders and carpetbaggers ${ }^{1}$ ).

Given the time difference between Prague and eastern Canada, that morning's top story on Headline News was the first I heard of events at Kanehsatà:ke, or as it was soon referred to, the 'Oka Crisis'. The previous

\footnotetext{
${ }^{1}$ The comparison with the original 'carpetbaggers' - northerners who headed to the defeated Confederate South at the end of the American Civil War, looking to make quick profits during Reconstruction - resonates strongly. The Soviet bloc was seen as having been defeated in the Cold War, and an influx of transient opportunists saw this as a chance to get quickly rich. In Mandevillean fashion, private vices would become public virtues, as the populace of the former East bloc received a crash course in capitalism from its least reputable proponents. The joke was still circulating in the former USSR well into the twenty-first century: 'Everything we knew about socialism was false, and everything we knew about capitalism was true'.
}

www.socialiststudies.com ISSN 1918-2821 
morning, on 11 July 1990, the Quebéc provincial police, the Sûreté du Quebéc (SQ), had moved in to remove a roadblock established by residents of the Mohawk reserve of Kanehsatà:ke near Montréal. The roadblock had been established in order to prevent the neighbouring francophone community of Oka from expanding a golf course. The proposed expansion was to take place on disputed land (as is most of Canada). In this case, the land in question was the remnant of an area known as 'the Pines', the site of a Mohawk burial ground which had been partially razed for the initial construction of the golf course in 1961. The community of Kanehsatà:ke sought at that time to prevent the clearing through legal channels; by the time the case was heard, much of the Pines had already been levelled. The issue was re-ignited in 1989 when the mayor of Oka, Jean Ouellette, announced that the remainder of the Pines would be cleared to expand the course. Residents of Kanehsatà:ke protested this decision, held demonstrations, and in the spring of 1990 erected a barricade to prevent the work.

The Sûreté du Quebéc moved in on the morning of 11 July with tear gas and stun grenades. There remains no agreement on who fired first, but the ensuing gun battle resulted in the death an SQ officer, Corporal Marcel Lemay, and the retreat of the SQ. The SQ abandoned their police cruisers and a bulldozer, which the Mohawks used to add to the barricade. The situation unfolded through the summer: the Royal Canadian Mounted Police (RCMP) were called in to replace the SQ, and later the Canadian armed forces were deployed. The nearby Mohawk community of Kahnawá:ke blockaded the Mercier Bridge, a major commuter route into Montréal, in solidarity with the people of Kanehsatà:ke. A peace camp in the town of Oka drew Aboriginal and non-Aboriginal supporters from throughout Canada and the world.

Meanwhile, tensions escalated around the barricade in Kanehsatà:ke, resulting in the vicious beating of one Mohawk warrior by the military. Canadian troops moved into the community of Kahnawá:ke, raiding the Longhouse (an act the Mohawks compared to desecrating a church or synagogue); while the police watched, a mob of locals, urged on by a talk-radio host, attacked a convoy of children, the elderly and the sick leaving Kahnawá:ke, hurling rocks and concrete blocks, resulting in the death of an elderly Mohawk man. An end to the blockade of the Mercier Bridge was negotiated on the following day, and the government of Quebéc then broke off further negotiations over Kanehsatà:ke. The Mohawks of 
THOMPSON: Post-Colonialism, Post-Socialism, and Multiple Remembrances

Kanehsatà:ke destroyed their remaining weapons and left the Pines on 26 September, with most immediately arrested by the military. ${ }^{2}$

I watched all this unfold through the fragments and sound bites of CNN, supplemented by news provided by my Czechoslovak students and friends. The 'Oka Crisis' was as riveting, and as shocking, for them as it was for me. Canadian Aboriginal peoples occupied a special place in the mythology of Czechoslovak childhood, thanks to the work of the novelist Karl May. May was a prolific writer of stories for children and adults at the end of the nineteenth century, selling over 100 million copies of his books in the original German and various translations, including Czech (King 2003). Czechoslovak school children grew up reading May's accounts of noble Canadian 'Indians', and cherished a belief in a benevolent Canadian state's relationship with its Aboriginal peoples, in sharp contrast to our neighbour to the south. My friends were as shocked and disturbed as was I to see images of armed Canadian soldiers confronting Mohawk warriorsjust a few minutes' drive from Montréal.

Such scenes did not fit with Czechoslovak's image of Canada at that time, nor that of most of the rest of the world - Canada like to be seen as the ultimate global do-gooder. In the subsequent twenty years, our Canadian complacency concerning relationships with First Nations have crumbled: Ipperwash; Esgenoopetitj; Caledonia; the admission of the catastrophe of the residential schools - all underscore the reality of the relationship. Non-aboriginal Canada was finally coming to recognise what its colonised original population had long known: that the history of the engagement of the Canadian state and society and First Nations was not one of harmonious tranquillity. The events of the summer of 1990 were a vivid notification that, as Mohawk scholar Taiaiake Alfred writes in his

\footnotetext{
${ }^{2}$ I have condensed a complex and hotly contested summary of the events of the summer of 1990 in the preceding two paragraphs. Numerous scholarly and popular considerations of these events are available (including one by one of our contributors to this issue), and the references can be found in the essays in the special section Twenty Years after Kanehsatà:ke: Reflections, Responses, Analyses in this issue.

The four-film series by the Abenaki filmmaker Alanis Obomsawin is the most powerful recounting of the event. Kanehsatake: 270 years of resistance chronicles the siege at Kanehsatà:ke from behind the barricade. My Name is Kahentiiosta recounts the tale of one woman arrested at the end of the siege, and the insistence by the legal system that she had to have a 'proper' French or English name. Spudwrench - Kahnawake Man is devoted to the Mohawk warrior beaten nearly to death by the military, and the role of Mohawk iron workers The final film, Rocks at Whiskey Trench, situates the attack on the convoy from Kahnawá:ke within the larger tale of lost land. See Obawsawin 2008.
} 
contribution to this issue's special section, Twenty Years after Kanehsatà:ke: Reflections, Responses, Analyses, '11 July 1990 was the day that shit ended'.

\section{9, 1990, 1991}

My presence in Czechoslovakia had been made possible by the variety of revolutions, velvet and otherwise, which had swept Central Europe in the fall of 1989, ushering in a new era and a new term, 'post-socialism', though we did not yet know the term. Two years after these revolutions, and a year after the events at Kanehsatà:ke and Kahnawá:ke, a non-revolution would bring about the speedy decay of the USSR. That convoluted late summer and autumn began with a bungled coup in August and petered out by December with fifteen separate sovereign and surprised new states. Such was the beginning of a new era of 'post-socialism', an era which would see my return to the post-socialist, post-communist, and post-Soviet world from 1998 to 2005, working for educational reform agencies, primarily in Kyrgyzstan, Tajikistan, and Uzbekistan. I was still trying to be a do-gooder, and still watching as the carpetbaggers won. Carpet-bagging had become a much more sophisticated operation than it had been in the naïve summer of 1990 in Central Europe. No longer was one trying to gain control of a fashionable pub where dissidents used to hang around, or corner the market on disposable paper products. ${ }^{3}$ The stakes had changed. This time round, we were talking about the control of oilfields, electrical grids, and transnational banking sectors.

Last year's twentieth anniversary of the revolutions of 1989 was marked with a flurry of conferences, publications, and special issues of scholarly journals; it is safe to assume that next year's anniversary of 1991 will be commemorated in a similar manner. 'Post-socialism' has become a major pastime, tied to research dollars and policy-making, with a bevy of centres mushrooming forth to dissect and analyze the post-socialist reality. Bracketed between 1989 and 1991, which launched us into 'postsocialism', do Kanehsatà:ke and Kahnawá:ke in the summer of 1990 have any relationship with the collapse of the state-socialist Soviet bloc, beyond historical contingency? The twentieth anniversary of the 'Oka Crisis' appears to have faded from the memory of my now Czech and Slovak

\footnotetext{
${ }^{3}$ I really did work with people who attempted both in Czechoslovakia (and did succeed in the former instance). The distance between 'biznezmen' and myself in Central Asia was infinitely greater.
} 
THOMPSON: Post-Colonialism, Post-Socialism, and Multiple Remembrances

colleagues, and the international community in general. Within Canada, Leanne Simpson's and Kiera L. Ladner's just-released edited collection, This is an Honour Song: Twenty Years since the Blockades (Ladner and Simpson 2010), reminds us of Kanehsatà:ke and Kahnawá:ke within the world of academic publishing. Are these events of no more than parochial interest, twenty tears on? Not surprisingly, I would not accept this interpretation. The last decade of the twentieth century did change the world, and the events at Kanehsatà:ke and Kahnawá:ke in the summer of 1990 were part of this transformation, a transformation in the selfconfidence of the capitalist world.

\section{What's Socialism got to do with it?}

When the call went out for this themed issue, it was greeted with puzzlement by many colleagues. The standard refrain was 'What has Oka got to do with socialism?' I could, of course, make the standard rejoinders, quoting the mission of this journal, and citing its commitment to anticolonial, anti-racist, and liberatory movements. But such gestures ring hollow, sounding much like an attempt to capitalize (and I use the word intentionally) on the struggles of the Mohawks of Kanehsatà:ke and

Kahnawá:ke. As David Bedford and Thomas Cheney note in their contribution within this issue, the response of the labour left to the 'Oka Crisis' resonated far more with fascism than with socialism. Making the case for the appearance of this issue of Socialist Studies demands further reflection on the relationships between the colonial and post-colonial with the socialist and post-socialist.

What once had been actually-existing socialism did not have a persuasive track record in terms of dealings with indigenous peoples. Marx's own work presumed the inevitability progressive character of the proletarianization of colonial peoples, a necessary push in to modern class relations (Marx 1979). The final decades of the USSR saw the massive influx of settlers into the Indigenous north (and especially into oilproducing regions), once again in the name of modernization (Thompson 2008). Closer to home for those of us in Canada, the CCF government in Saskatchewan, from its election until its demise as government and party in 1967, adhered to a policy of modernization in the north of the province in part to assimilate the Cree and Dene populations, and in part to implement a more 'socialist' agenda than was possible in the more heavily populated south (Quiring 2004). The conflict between the Miskito people of Nicaragua and the Sandinista regime in the 1980s provoked 
uncomfortable stammering amongst anti-imperialists worldwide. The legacy of the left in power, in Canada and internationally, has not been one to inspire confidence amongst Indigenous peoples. Only the anarchist left, calling on tradition dating back to Bakunin, could make any kind of serious claim to a non-teleological view of modernity, and the concomitant possibility of diversity (Bakunin 1990). This claim was forced out of sight, however, beginning with the fracturing of the First International in 1872 and culminating in the crushing of the Kronstadt Uprising in 1921. Moments such as that of Evo Morales and the Movimiento al Socialismo 2005 and 2009 electoral victories in Bolivia, wherein Indigenous peoples are a majority, remain rare.

But despite its failures in practice, the ideal of a socialist alternative placed limits upon capitalism. Intellectuals as diverse as CB Macpherson on the left and George Grant on the right were able to recognise that throughout its duration, the very existence of the USSR suggested that there were alternatives to global capitalism, and served as some form of check $^{4}$ on the extreme excesses of a capitalist economy backed up by the force of the state (Macpherson 1973; Grant 2005). Stripped of this modest ethical limitation, capitalism in the post-socialist world knew no limits. A triumphalist neoliberal cast could declare the end of history (Fukuyama 1992), and the inevitability of liberal democracy (with an emphasis on the 'liberal' side of the term). Capitalism, not Marxism, had been vindicated by the forces of history, and free-market economics in its classical form could now be accepted as a universally-acknowledged and incontrovertible scientific truth (Klein 2008).

The conjunction of the events at Kanehsatà:ke and the coming end of Soviet communism was on the mind of one Plains Cree visual artist, Gerald McMaster, who did a series of works in 1990 which were part of a 1992 exhibition Indigena, marking 500 years of grappling with the legacy of Columbus. Some of these works explicitly reference Kanehsatà:ke, such as Oka-boy / Oh! Kowboy and No Life Like It. But his work Glasnost is of particular interest to me here. The painting features caricatures of a 'cowboy' and an 'Indian', overwritten with the following text:

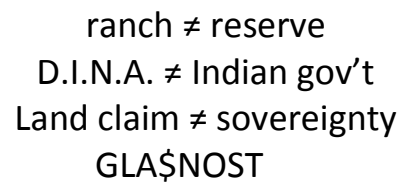

\footnotetext{
${ }^{4}$ Such checks may have seemed negligible to the residents of proxy states during the Cold War.
} 
THOMPSON: Post-Colonialism, Post-Socialism, and Multiple Remembrances

I would also refer readers to Wanda Nanibush's 'Love and Other Resistances' and reproductions of the pieces in This is an Honour Song (Nanibush 2010), ${ }^{5}$ but it seems safe to suggest that we can see a collision amongst a colonial imagination, events in the socialist and post-socialist world, capitalism, and First Nations' sovereignty.

Within the light of post-socialist capitalism, the confrontation of the summer of 1990 between the Canadian and Québec states and the peoples of Kanehsatà:ke and Kahnawá:ke could be read as an early flexing of state power in a post-socialist era, wherein the sacrosanct character of colonial property relations - a golf course and a commuter bridge -trumped any other forms of rights to land, spirituality, or human dignity. The images of stare-downs between Canadian soldiers and Mohawk warriors encapsulates how things were to unfold in the wake of socialist alternatives.

\section{States and Non-States, Land and History}

Part of socialism's difficulty in coming to terms with issues of aboriginality are tied to its difficulty in coming to terms with its kindred spirit, capitalism - the two are twin children of the Enlightenment project, invoking the rational ordering of the world. The constitution of 'rational' may be the subject of considerable disagreement, but these two vectors of Enlightenment thought shared a faith in an historical progress which would necessarily and intentionally sweep aside all 'pre-modern' forms of social organisation (Horkheimer and Adorno 1972; Arendt 1968; Beilharz 2009; Lefort 1986). As progeny of the Enlightenment, capitalism and this form of socialism shared the epistemological certainty of having a monopoly on understanding the reality of the world.

Common to this shared certainty was the belief in the static nature of peoples engulfed by European colonialism. The colonized world was understood as enmeshed in social relationships which had frozen, remaining unchanged since the dim recesses of the past. Only the force of colonialism and the active intervention of the colonial state could break this stasis and re-insert the colonized within historical time (Scott 2009; Sahlins 2000; Cohn 1996). Within Europe, it was neither liberals nor socialists who challenged this view, but conservatives, suggesting that such an effort would undermine the colonial power itself (Burke 1857).

\footnotetext{
${ }^{5}$ For discussions of some of the other artists included in the work, see also Paul Chaat Smith's Everything You Know about Indians is Wrong (Smith 2009), reviewed in this issue.
} 
Canada's own contribution to such thought was made by the hapless Lieutenant Governor of Upper Canada, Francis Bond Head, who in addition to sparking the 1837 Rebellion, successfully advocated for the establishment of what would evolve into the Canadian reserve system, isolating First Nations from settler Canada (Ray 2005). But the presumption of stasis remained unchallenged. Within the Americas, this took the form of 'Indians' as being static (outside of history) and a single, homogenous group. All Aboriginal peoples were ultimately the same.(Lutz 2008).

An alternative reading of colonized cultures emerges from what has come to be known, for good or for ill, as 'post-colonial'. Such perspectives need not suggest that the era of colonialism has come to an end; it obviously has not, as the events of 1990 and today should remind us. But the colonized are not, and have never been, passive and inert objects in the colonial dialectic. The colonized may have operated outside the epistemology of Enlightenment progress, culminating in the Hegelian fusion of state and capitalism, but this does not imply existing outside of history. As Pierre Clastres and James C. Scott have both argued, the prevention of state and capital formation have in themselves been historical actions (Clastres 1987; Scott 2010).

The re-opening of history also creates challenges for the certainty of the written word, a fact well-understood within the legacy of First Nations' oral traditions in Canada. This confounds the conventions of that academic sanctification of the written word, the scholarly journal. Within this issue, one will encounter varied terms and spellings, some mandated by colonial logic (the Canadian state recognises the 'Mohawks of Kanesatake', as a nation, not those of 'Kanehsatà:ke' or 'Kanehsatake'). While my own editorial obsessions have usually led me to standardize 'Kanehsatà:ke' and 'Kahnawá:ke' (although even with these, reasons of indexing at time resist such efforts), by and large we have left terminology in the forms which the authors had used. Thus, at some points terms may be given in English translations; at others, they may be given in the language of the Haudenosaunee (or the 'Iroquois', or the 'Mohawks', or the 'Kanien'hekaka'). Perhaps the lack of consensus does not need a resolution, but should instead remain as part of these perpetually emergent histories.

What remains, of socialism and post-socialism, colonialism and post-colonialism, is history - a history which has set itself on a different path than that of Enlightenment teleology in its capitalist or socialist forms. The Dene scholar Glen Coulthard follows Franz Fanon in rejecting the 
THOMPSON: Post-Colonialism, Post-Socialism, and Multiple Remembrances

'assimilative lure' of a politics of recognition, demanding instead an autonomous and autochthonous search for concepts of First Nations' sovereignty (Coulthard 2008, 201), notions pursued by Kahente Doxtater (Horn-Miller) and Stephen W. Koptie in their contributions to this issue. The end of Soviet-style state socialism was proclaimed as the end of history and the triumph of liberalism; McMaster, Coulhardt, Doxtater, and Koptie all seek to re-open history beyond the stasis of the colonial imagination.

Post-socialism, for the co-founder of Thesis Eleven, Peter Beilharz, is not the end of history but the return to history, one which moves beyond the convictions of certainty in how the world must unfold (Beilharz 2009). Such a claim echoes a remark made by author Thomas King at an address at Nipissing University in North Bay, Ontario in 2009. King spoke of the continuing incomprehension by settler states and societies when challenged by Aboriginal claims to sovereignty. Settler Canada, according to King, inserted issues of land and history alongside considerations of politics, economics, and myriad other processes, insisting on an appreciation of the complexity of the entire question. What we continually failed to understand, according to King, was that this was not primarily about land and history; it was all about land and history. The challenge for the contemporary left, socialist or post-socialist, is to understand what this means for us today.

\section{References}

Arendt, Hannah. 1968. The Origins of Totalitarianism, new edition with added prefaces. Harmondsworth: Penguin Books.

Bakunin, Mikhail. 1990. Statism and Anarchy. Cambridge: Cambridge University Press.

Beilharz, Peter. 2009. Socialism and Modernity. Minneapolis: University of Minnesota Press.

Burke, Edmund. 1855. "Speech on Mr. Fox's East India Bill." In Works of the Right Honourable Edmund Burke, vol. 2, D.B. Horn and Mary Ransome (eds). London: Henry G. Bohn.

Clastres, Pierre. 1987. Society Against the State: Essays in Political Anthropology. New York: Zone Books.

Cohn, Bernard S. 1996. Colonialism and its Forms of Knowledge. Princeton: Princeton University Press.

Coulthard, Glen. 2008. "Beyond Recognition: Indigenous Self-Determination as Prefigurative Practice." In Lighting the Eighth Fire: the Liberation, Resurgence, and Protection of Indigenous Nations, Leanne Simpson (ed.). Winnipeg: Arbeiter Ring Publishing. 
Fukuyama, Francis. 1992. End of History and the Last Man. New York: Avon.

Grant, George. 2005. Lament for a Nation: the Defeat of Canadian Nationalism. Montréal: McGill-Queen's University Press.

Horkheimer, Max and Theodor W. Adorno. 1972. Dialectic of Enlightenment. New York: Continuum.

Klein, Naomi. 2008. The Shock Doctrine: the Rise of Disaster Capitalism. Toronto: Vintage Canada.

Lefort, Claude. 1986. The Political Forms of Modern Society: Bureaucracy, Democracy, Totalitarianism. Cambridge: The MIT Press.

Lutz, John Sutton. 2008. Makúk: A New History of Aboriginal-White Relations. Vancouver: UBC Press.

Macpherson, C.B. 1973. Democratic Theory: Essays in Retrieval. Oxford: Clarendon Press.

Marx, Karl. 1979. "The British Rule in India." In Marx-Engels Collected Works, vol. 12. New York: Progress Publishers.

McMaster, Gerald. 2010. "Glasnost." In This is an Honour Song: Twenty Years Since the Blockades, Leanne Simpson and Kiera L. Ladner (eds.). Winnipeg: Arbeiter Ring Publishing.

Nanibush, Wanda. 2010. "Love and Other Resistances: Responding to Kanehsatà:ke through Artistic Practice." In This is an Honour Song: Twenty Years Since the Blockades, Leanne Simpson and Kiera L. Ladner (eds.). Winnipeg: Arbeiter Ring Publishing.

Obomsawin, Alanis. 2008. Alanis Obomsawin - the Collection: 270 Years of Resistance. Ottawa: National Film Board of Canada.

Ray, Arthur J. Ray. 2005. I Have Lived Here Since the World Began: an Illustrated History of Canada's Native People, revised edition. Toronto: Key Porter.

Sahlins. Marshall. 2000. "Cosmologies of Capitalism: the Trans-Pacific Sector of "The World System'." In Culture in Practice: Selected Essays. New York: Zone Books.

Scott, James C. 2009. The Art of Not Being Governed: an Anarchist History of Upland Southeast Asia. New Haven: Yale University Press.

Simpson, Leanne and Kiera L. Ladner. 2010. This is an Honour Song: Twenty Years Since the Blockades. Winnipeg: Arbeiter Ring Publishing.

Thompson, Niobe. 2008. Settlers on the Edge: Identity and Modernization of Russia's Arctic Frontier. Vancouver: UBC Press. 